STATE OF ILLINOIS

DEPARTMENT OF REGISTRATION AND EDUCATION

DIVISION OF THE

NATURAL HISTORY SURVEY

STEPHEN A. FORBES, ChIel

\begin{tabular}{lll}
\hline Vol. XV. BULLETIN & Article IX. \\
\hline
\end{tabular}

\title{
The Lake as a Microcosm
}

BY

STEPHEN A. FORBES

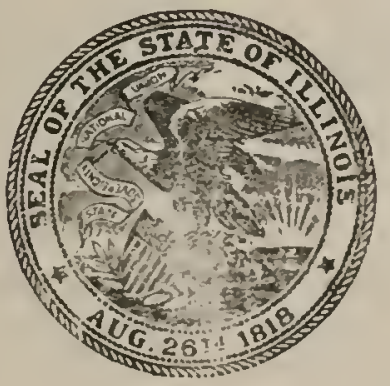

PRINTED BY AUTHORITY OF THE STATE OF ILLINOIS

URBANA, ILLINOIS

November, 1925 
STATE OF ILLINOIS

DEPARTMENT OF REGISTRATION AND EDUCATION

A. M. Shelton, Director

\section{BOARD OF \\ NATURAL RESOURCES AND CONSERVATION}

A. M. Shelton, Chairman

William Trelease, Biology

JoHN M. Coulter, Forestry

Edson S. Bastin, Geology

Wrltam A. Noyes, Chemistry
JohN W. Alvokd, Engineering

Kendric C. BABCOCK, Representing the

President of the University of Illinois

\section{THE NATURAL HISTORY SURVEY DIVISION}

StePIIEN A. Forbes, Chicf 
Article IX.-The Lake as a Microcosm*. By Stephen A. Forbes.

A lake is to the naturalist a chapter out of the history of a primeval time, for the conditions of life there are primitive, the forms of life are, as a whole, relatively low and ancient, and the system of organic interactions by which they influcnce and control each other has remained substantially unchanged from a remote geological period.

The animals of such a body of water are, as a whole, remarkably isolated-closely related among themselves in all their interests, but so far independent of the land about them that if every terrestrial animal were suddenly annihilated it would doubtless be long before the general multitude of the inhabitants of the lake would feel the effects of this event in any important way. It is an islet of older, lower life in the midst of the higher, more recent life of the surounding region. It forms a little world within itself - a microcosm within which all the elemental forces are at work and the play of life goes on in full, but on so small a scale as to bring it easily within the mental grasp.

Nowhere can one see more clearly illustrated what may be called the sensibility of such an organic complex, expressed by the fact that whatever affects any species belonging to it, must have its influence of some sort upon the whole assemblage. He will thus be made to see the impossibility of studying completely any form out of relation to the other forms; the necessity for taking a comprehensive survey of the whole as a condition to a satisfactory understanding of any part. If one wishes to become acquainted with the black bass, for example. he will learn but little if he limits himself to that species. He must evidently study also the species upon which it depends for its existence, and the various conditions upon which these depend. He must likewise study the species with which it comes in competition, and the entire system of conditions affecting their prosperity; and by the time he has studied all these sufficiently he will find that he has run through the whole complicated mechanism of the aquatic life of the locality, both animal and regetable, of which his species forms but a single element.

It is under the influence of these general ideas that I propose to examine briefly to-night the lacustrine life of Illinois, drawing my data

- This paper ortginally read Fcliuary 25, 1887, ta the Peoria Sclentifc Associa. thon (now extinct), and published in thelr Bulletin, was reprintcd many years ago by the Illinois State Laboratory of Natural Illstory in an edition whlch has long been out of print. A single cony remaining in the library of the Natural History Survey is used every yoar by classus in the iniversity of 1111nois, and a professul of zoulogy in a Canadin university horrows a copy regularly from a penria llbmry for uge in hls own class.s. In view of this long-continued demand and in

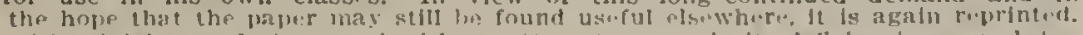
with trivfal entondations. and with mo attempt to supply its dellefencles or in lirlug It down to date. 
from collections and observations made during recent years by myselt and my assistants of the State Laboratory of Natural History.

The lakes of Illinois are of two kinds, fluviatile and water-shed. The fluviatile lakes, which are much the more numerous and important, are appendages of the river systems of the state, being situated in the river bottoms and connected with the adjacent streams by periodical overflows. Their fauna is therefore substantially that of the rivers themselves, and the two shonld, of conrsc, be studied together.

They are probably in all cases either parts of former river channels, which have been cut off and abandoned by the current as the river changed its course, or else are tracts of the high-water beds of streams over which, for one reason or another, the periodical deposit of sediment has gone on less rapidly than over the surrounding area, and which have thus come to form depressions in the surface which retain the waters of overflow longer than the higher lands adjacent. Most of the numerous "horseshoe lakes" belong to the first of these varieties, and the "bluff-lakes," situated along the borders of the bottoms, are many of them examples of the second.

These fluviatile lakes are most important breeding grounds and reservoirs of life, especially as they are protected from the filth and poison of towns and manufactories by which the rumning waters of the state are yearly more deeply defiled.

The amount and variety of animal life contained in them as well as in the streams related to them is extremely variable, depending chiefly: on the frequency, extent, and duration of the spring and summer overflows. This is, in fact, the characteristic and peculiar feature of life in these waters. There is perhaps no better illustration of the methods by which the flexible system of organic life adapts itself, without injury, to widely and rapidly fluctuating conditions. IThenever the waters of the river remain for a long time far beyond their banks, the breeding grounds of fishes and other animals are immensely extended, and their food supplies increased to a corresponding degree. The slow or stagnant backwaters of such an overflow afford the best situations possible for the development of myriads of Entomostraca, which furnish, in turn, abundant food for young fishes of all descriptions. There thus results an outpouring of life-an extraordinary multiplication of nearly: every species, most prompt and rapid, generally speaking, in such as have the highest reproductive rate, that is to say, in those which produce the largest average number of eggs and young for each adult.

The first to feel this tremendous impulse are the protophytes and Protozoa, upon which most of the Entomostraca and certain minute insect larvæ depend for food. This sudden development of their food resources causes, of course, a corresponding increase in the numbers of the latter classes, and, through them, of all sorts of fishes. The first inshes to feel the force of this tidal wave of life are the rapidly-breeding. non-predaceous kinds; and the list. the same fishes, which derive from the others their principal food supplies. Evidently each of these classes 
must act as a check upon the one preceding it. The devclopment of animalcules is arrested and soon sent back below its highest point by the consequent development of Entomostraca; the latter, again, are met, checked, and reduced in number by the innumerable shoals of fishes with which the water speedily swarms. In this way a general adjustment of numbers to the new conditions would finally be reached spontaneously; but long before any such settled balance can be established, often of course before the full effect of this upward influence has been exhibited, a new cause of disturbance intervenes in the disappcarance of the overflow. As the waters retire, the lakes are again defined; the teeming life which they contain is restricted within daily narrower bounds, and a fearful slaughter follows; the lower and more defenceless animals are penned up more and more closely with their predaceous enemies, and these thrive for a time to an extraordinary degree. To trace the further consequences of this oscillation would take me too far. Enough has been said to illustrate the gencral idea that the life of waters subject to periorlical expansions of consiclerable duration, is peculiarly unstable and utuctuat.ng; nat eacn species swings, pendulumlike but irregularly, between a highest and a lowest point, and that this fluctuation affects the different classes successively, in the order of their dependence upon each other for food.

Where a water-shed is a nearly level plateau with slight irregularities of the surface many of these will probably be imperfectly drained, and the accumulating waters will form either marshes or lakes according to the depth of the depressions. Highland marshes of this character are seen in Ford, Livingston, and adjacent counties, ${ }^{*}$ between the headwaters of the Illinois and Wahash systems; and an area of water-shed lakes occurs in Lake and McHenry counties, in northern Illinois.

The latter region is everywhere broken by low, irregular ridges of glacial drift, with no rock but boulders anywhere in sight. The intervening hollows are of every variety. from mere sink-holes, either dry or occupied by ponds, to expanses of several square miles, forming marshes or lakes.

This is, in fact, the southern end of a broad lake belt which borders Lakes Michigan and Superior on the west and south, extending through eastern and northern Wisconsin and northwestern Minnesota, and occupying the plateau which scparates the headwaters of the St. Lawrence from those of the Mississippi. These lakes are of glacial origin, some filling heds excavated in the solid rock, and others collecting the surface waters in hollows of the drift. The latter class, to which all the Illinois lakes belong, may lie either parallel to the line of glacial action, occupying valleys between adjacent lateral moraines, or transverse to that line and bounded by terminal moraines. Those of our own state

-All now dralned and brought under cultivation. 
all drain at present into the Illinois through the Des Plaines and Fox; but as the terraces around their borders indicate a former water-level considerably higher than the present one it is likely that some of them once emptied eastward into Lake Michigan. Several of these lakes are clear and beautiful sheets of water, with sandy or gravelly beaches, and shores bold and broken enough to relieve them from monotony. Sportsmen long ago discovered their advantages and club-houses and places of summer resort are numerous on the borders of the most attractive and easily accessible. They offer also an unusually rich field to the naturalist, and their zoology and botany should be better known.

The conditions of aquatic life are here in marked contrast to those afforded by the fluviatile lakes already mentioned. Connected with each other or with adjacent streams only by slender rivulets, varying but little in level with the change of the season and scarcely at all from year to year, they are characterized by an isolation, independence, and uniformity which can be found nowhere else within our limits.

Among these Illinois lakes I did considerable work during October of two successive years, using the sounding line, decp-sea thermometer, towing net, dredge, and trawl in six lakes of northern Illinois, and in Geneva Lake, Wisconsin, just across the line. Upon one of these Illinois lakes I spent a week in October, and an assistant, Prof. H. Garman, now of the University, spent two more, making as thorough a physical and zoölogical survey of this lake as was possible at that season of the year.

I now propose to give you in this paper a brief general account of the physical characters and the fauna of these lakes, and of the relations of the one to the other; to compare, in a general way, the animal assemblages which they contain with those of Lake Michigan - -where also I did some weelis of active aquatic work in 1881-and with those of the fluviatile lakes of central Illinois; to make some similar comparisons with the lakes of Europe; and, finally, to reach the subject which has given the title to this paper-to study the system of natural interactions by which this mere collocation of plants and animals has been organized as a stable and prosperous community.

First let us endeavor to form the mental picture. To make this more graphic and true to the facts, I will describe to you some typical lakes among those in which we worked; and will then do what I can to furnish you the materials for a picture of the life that swims and creeps and crawls and burrows and climbs through the water, in and on the bottom, and among the feathery water-plants with which large areas of these lakes are filled.

Fox Lake, in the western border of Lake county, lies in the form of a broad irregular crescent, truncate at the ends, and with the concavity of the crescent to the northwest. The northern end is broadest and communicates with Petite Lake. Two points projecting inward from the southern shore form three broad bays. The western end opens into Nippisink Lake, Crab Island separating the two. Fox River 
enters the lake from the north, just eastward of this island, and flows directly through the Nippisink. The length of a curved line extending through the central part of this lake, from end to end, is very nearly three miles, and the width of the widest part is about a mile and a quarter. The shores are bold, broken, and wooded, except to the north, where they are marshy and flat. All the northern and eastern part of the lake was visibly shallow-covered with weeds and feeding waterfowl, and I made no soundings there. The water there was probably nowhere more than two fatlooms in depth, and over most of that area was doubtless under one and a half. In the western part, five lines of soundings were ruin, four of them radiating from Lippincott's Point, and the fifth crossing three of these nearly at right angles. The deepest water was found in the middle of the mouth of the western bay, where a small area of five fathoms occurs. On the line running northeast from the Point, not more than one and three fourths fathoms is found. The bottom at a short distance from the shores was everywhere a soft, deep mud. Four hauls of the dredge were made in the western bay, and the surface net was dragged about a mile.

Long Lake differs from this especially in its isolation, and in its smaller size. It is about a mile and a half in length by a mile in breadth. Its banks are all bold except at the western end, where a marshy valley traversed by a small creek connects it with Fox Lake, at a distance of about two miles. The deepest soundling made was six and a half fathoms, while the average depth of the deepest part of the bed was about five fathoms.

Cedar Lake, upon which we spent a fortnight, is a pretty sheet of water, the head of a chain of six lakes which open finally into the Fox. It is about a mile in greatest diameter in each direction, with a small but charming island bank near the center, covered with bushes and vines-a favorite home of birds and wild flowers. The shores vary from rolling to bluffy except for a narrow strip of marsh through which the outlet passes, and the bottoms and margins are gravel, sand, and mud in different parts of its area. Much of the lake is shallow and full of water plants; but the southern part reaches a depth of fifty feet a short distance from the eastern bluff.

Deep Lake, the second of this chain, is of similar character, with a greatest depth of fifty-seven feet-the deepest sounding we made in these smaller lakes of Illinois. In these two lakes several temperatures were taken with a differential thermometer. In Deep Lake, for example, at fifty-seven feet I found the bottom temperature $531 / 2^{\circ}-$ about that of ordinary well-water-when the air was $63^{\circ}$; and in Cedar Lake, at forty-eight feet, the bottom was $58^{\circ}$ when the air was $61^{\circ}$.

Geneva Lake, Wisconsin, is a clear and beautiful body of water about eight miles long by one and a quarter in greatest width. The banks are all high. rolling, and wor elerl, cxecpt at the castern cud, where its outlet rises. Its deepest water is found in its western third, where it reaches a depth of twenty-three fathoms. I made here, early in Novem- 
ber, twelve hauls of the dredge and three of the trawl, aggregating about three miles in length, so distributed in distance and depth as to give a good idea of the invertebrate life of the lake at that season.

And now if you will kindly let this suffice for the background or setting of the picture of lacustrine life which I have undertaken to give you, I will next endeavor-not to paint in the picture; for that I have not the artistic skill. I will confine myself to the humble and safer task of supplying you the pigments, leaving it to your own constructive imaginations to put them on the canvas.

When one sees acres of the shallower water black with water-fowl, and so clogged with weeds that a boat can scarcely be pushed through the mass; when, lifting a handful of the latter, he finds them covered with shells and alive with small crustaceans; and then, dragging a towing net for a few minutes, finds it lined with myriads of diatoms and other microscopic algæ, and with multitudes of Entomostraca, he is likely to infer that these waters are everywhere swarming with life, from top to bottom and from shore to shore. If, however, he will haul a dredge for an hour or so in the deepest water he can find, he will invariably discover an area singularly barren of both plant and animal life, yielding scarcely anything but a small bivalve mollusk, a few low worms, and red larvæ of gnats. These inhabit a black, deep, and almost impalpable mud or ooze, too soft and unstable to afford foothold to plants even if the lake is shallow enough to admit a sufficient quantity of light to its bottom to support vegetation. It is doubtless to this character of the bottom that the barrenness of the interior parts of these lakes is due; and this again is caused by the selective influence of gravity upon the mud and detritus washed down by rains. The heaviest and coarsest of this material necessarily settles nearest the margin, and only the finest silt reaches the remotest parts of the lakes, which, filling most slowly, remain, of course, the deepest. This ooze consists very largely, also, of a fine organic debris. The superficial part of it contains scarcely any sand, but has a greasy feel and rubs away, almost to nothing, between the fingers. The largest lakes are not therefore, as a rule, by any means the most prolific of life, but this shades inward rapidly from the shore, and becomes at no great distance almost as simple and scanty as that of a desert.

Among the weeds and lily-pads upon the shallows and around the margin-the Potamogeton, Myriophyllum, Ceratophyllum, Anacharis, and Chara, and the conmon Nelumbium,- - among these the fishes chiefly swim or lurk, by far the commonest being the barbaric bream ${ }^{1}$ or "pumpkin-seed" of northern Illinois, splendid with its green and scarlet and purple and orange. Little less abundant is the common perch (Percu lutea) in the larger lakes-in the largest out-numbering the bream itself. The whole sunfish family, to which the latter belongs, is in fact the dominant group in these lakes. Of the one hundred and thirty-two fishes of Illinois only thirty-seven are found in these waters-about twenty-

${ }^{1}$ Lepomis gibbosus. 
eight per cent.-while eight out of our seventeen sunfishes (Ceutrarchinac) have been taken ticere. Next, perhaps, one searching the pebbly beaches or scanning the weedy tracts will be struck by the small number of minnows or cyprinoids which catch the eye or come out in the net. Of our thirty-three Illinois cyprinoids, only six occur thereabout eighteen per cent.-and only three of these are common. These are in part replaced by shoals of the beautiful little silversides (Labidesthes sicculus), a spiny-finned fish, bright, slender, active, and voracious -as well suppliel with teeth as a perch, and far better equipped for self-defense than the soft-bodied and toothless cyprinoids. Next we note that of our twelve catfishes (Siluridae) only two have been taken in these lakes-one the common bullhcad (Ictalurus nebulosus), which occurs everywhere, and the other an insignificant stone cat, not as long as one's thumb. The suckers, also, are much less abundant in this region than farther south, the buffalo fishes ${ }^{1}$ not appearing at all in our collections. Their family is represented by worthless carp by two redhorse ${ }^{3}$, by the chub sucker ${ }^{4}$ and the common sucker (Catostomus teres), and by one other species. Even the hickory shad ${ }^{3}$-an ichthyological weed in the Illinois-we have not found in these lakes at all. The sheepshead ${ }^{6}$, so common here, is also conspicuous there by its absence. The yellow bass ${ }^{\top}$, not rare,in this river, we should not expect in these lakes because it is, rather, a southern species; but why the white bass $^{8}$, abundant here, in Lake Michigan, and in the Wisconsin lakes, should be wholly absent froni the lakes of the Illinois plateau, I am unable to imagine. If it occurs there at all, it must be rare, as I could neither find nor hear of it.

A characteristic, abundant, and attractive little fish is the log perch (Percina caprodes) -the largest of the darters, slender, active, barred like a zebra, spending much of its time in chase of Entomostraca among the water plants, or prying curiously about among the stones for minutc insect larvat. Six darters in all (Ethcostomatinae), out of the eighteen from the state, are on our list from these lakes. The two black bass ${ }^{0}$ are the most popular game fishes-the large-mouthed species being much the most alsumdant. The pickerels ${ }^{19}, \operatorname{gar}^{11}$, and dugfish ${ }^{13}$ are there alout as here; hut the shovel-fish ${ }^{13}$ docs not occur.

Of the peculiar fish fauna of Lakc Michigan-the burbot ${ }^{14}$, white fish, ${ }^{15}$ trout, ${ }^{16}$ lake herring or cisco, ${ }^{17}$ etc., not one species occurs in these smaller lakes, and all attempts to transfer any of them have failed completely. The cisco is a notable fish of Geneva Lake, IVisconsin, but does not reach Illinois except in Lake Michigan. It is useless to attempt to introduce it, because the deeper areas of the interior lakes are too limited to give it sufficient range of cool water in midsummer.

In short, the fishes of these lakes are substantially those of their

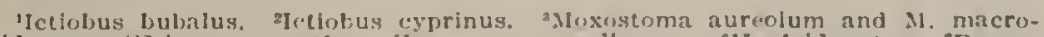
lepidotum. "firmyzon sucelta. "Dorosnnia cepedlanum. Haploidonolus. "Roccus

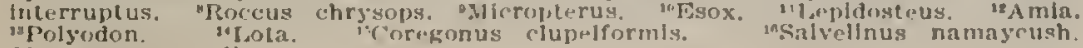
"Coregonus intedi. 
region-excluding the Lake Michigan series (for which the lakes are too small and warm) and those peculiar to creeks and rivers. Possibly the relative scarcity of catfishes (Siluridae) is due to the comparative clearness and cleanness of these waters. I see no good reason why minnows should be so few, unless it be the abundance of pike and Chicago sportsmen.

Concerning the molluscan fauna, I will only say that it is poor in bivalves-as far as our observations go-and rich in univalves. Our collections have been but partly determined, but they give us three species of Valvata, seven of Planorbis, four Amnicolas, a Melantho, two Physas, six Limnæas, and an Ancylus among the Gastropoda, and two Unios, an Anodonta, a Sphærium, and a Pisidium among the Lamellibranchiates. Pisiduin variabile is by far the most abundant mollusk in the oozy bottom in the deeper parts of the lakes; and crawling over the weeds are multitudes of small Amnicolas and Valvatas.

The entomology of these lakes I can merely touch upon, mentioning only the most important and abundant insect larvæ. Hiding under stones and driftwood, well aware, no doubt, what enticing morsels they are to a great variety of fishes, we find a number of species of ephemerid larvæ whose specific determination we have not yet attempted. Among the weeds are the usual larva of dragon-flies-Agrionina and Libellulina, familiar to every one; swimming in open water the predaceous larvæ of Corethra; wriggling through the water or buried in the mud the larvæ of Chironomus-the shallow water species white, and those from the deeper ooze of the central parts of the lakes blood-red and larger. Among Chara on the sandy bottom are a great number and variety of interesting case-worms-larvæ of Phryganeidæ-most of them inhabiting tubes of a slender conical form made of a viscid secretion exuded from the mouth and strengthened and thickened by grains of sand, fine or coarse. One of these cases, nearly naked, but usually thinly covered with diatoms, is especially worthy of note, as it has been reported nowhere in this country except in our collections, and was indeed recently described from Brazil as new. Its generic name is Lagenopsyche, but its species undetermined. These larva are also eaten by fishes.

Among the worms we have of course a number of species of leeches and of planarians,-in the mud minute Anguilitulidæ, like vinegar eels, and a slender Lumbriculus which nakes a tubular mud burrow for itself in the deepest water. and also the curious Nais probiscidca, notable for its capacity of multiplication by transverse division.

The crustacean fauna of these lakes is more varied than any other group. About forty species were noted in all. Crawfishes were not especially abundant, and nost belonged to a single species, Cambarus virilis. Two amphipods occurred frequently in our collections; one, less common here but very abunciant farther south-Crangony:t gracilisand one, Allorchestes dentata, probably the commonest aninal in these waters, crawling and swimming everywhere in myriads among the sub- 
merged water-plants. An occasional Gammarus fasciatus was also taken in the dredge. A few isopod Crustacea occur, bclonging to Mancasellus tenax-a species not previously found in the state.

I have reserved for the last the Entomostraca-minute crustaceans of a surprising number and varjety, and of a beauty of ten truly exquisite. They belong wholly, in our waters, to the three orders, Copedoda, Ostracoda, and Cladocera-the first two predaceous upon still smaller organisms and upon each other, and the last chiefly vegetarian. Twentyone species of Cladocera have been recognized in our collections, representing sixteen genera. It is an interesting fact that twelve of these species are found also in the fresh waters of Europe. Five cyprids have been detected, two of them common to Europe, and also an abundant Diaptomus, a variety of a European species. Several Cyclops species were collected which have not yet been determined.

These Entomostraca swarm in microscopic myriads among the weeds along the shore, some swimming freely, and others creeping in the mud or climbing over the leaves of plants. Some prefer the open water, in which they throng locally like shoals of fishes, coming to the surface preferably by night, or on dark days, and sinking to the bottom usually by day to avoid the sunshine. These pelagic forms, as they are called, are often exquisitely transparent, and hence almost invisible in their native element-a cliarming device of Nature to protect them against their enemies in the open lake, where there is no chance of shelter or escape. Then with an ingenuity in which one may almost detect the flavor of sarcastic humor, Nature has turned upon these favored children and endowed their most deadly enemies with a like transparency, so that wherever the towing net brings to light a host of these crystalline Cladocera, there it discovers also swimming, invisible, among them, a lovely pair of rohbers and beasts of prey-the delicate Leptodora and the Corethra larva.

These slight, transparent, pelagic forms are much more numerous in Lake Michigan than in any of the smaller lakes, and peculiar forms occur there conmonly which are rare in the larger lakes of Illinois and entirely wanting in the smallest. The transparent species are also much more abundant in the isolated smaller lakes than in those more directly connected with the rivers.

The vertical range of the animals of Geneva Lake showed clearly that the harrenness of the interiors of these small bodies of water was not due to the greater depth alone. Whilc there were a few species of crustaccans and case-worms which occurred there abunclantly near shore but rarely or not at all at depths greater than four fathons, and may hence be called littoral species, there was, on the whole, little diminution either in quantity or variety of animal life until about fiftecn fathouns had been reached. Dredging, at four or five fathoms were nearly or quite as fruitful as any made. On the other hand, the barremness of the bottom at twenty to twenty-three fathoms wats very ranarkable. The total product of four hauls of the dredge and one of the 
trawl at that depth, aggregating fully a mile and a half of continuous dragging, would easily go into a two-dram vial, and represents only nine animal species-not counting dead shells, and fragments which had probably floated in from shallower waters. The greater part of this little collection was composed of specimens of Lumbriculus and larvæ of Chironomus. There were a few Corethra larvæ, a single Gammarus, three small leeches, and some sixteen mollusks, all but four of which belonged to Pisidium. The others were two Sphæriums, a Valrata carinata, and a $V$. sincera. None of the species taken here are peculiar, but all were of the kinds found in the smaller lakes, and all occurred also in shallower water. It is evident that these interior regions of the lakes must be as destitute of fishes as they are of plants and lower animals.

While none of the deep-water animals of the Great Lakes were found in Geneva Lake, other evidences of zoölogical affinity were detected. The towing net yielded almost precisely the assemblage of species of Entomostraca found in Lake Michigan, including many specimens of Limnocalanus macrurus Sars; and peculiar long, smooth leeches, common in Lake Michigan but not occurring in the small, Illinois lakes, were also found in Geneva. Many Valvata tri-carinata lacked the middle carina, as in Long Lake and other isolated lakes of this region.

Comparing the Daphnias of Lake Michigan with those of Geneva Lake, Wis. (nine miles long and twenty-three fathoms in depth), those of Long Lake, Ill. (one and a half miles long and six fathoms deep), and those of other, still smaller, lakes of that region, and the swamps and smaller ponds as well, we shall be struck by the inferior development of the Entomostraca of the larger bodies of water in numbers, in size and robustness, and in reproductive power. Their smaller numbers and size are doubtless due to the relative scarcity of food. The system of aquatic animal life rests essentially upon the vegetable world, although perhaps less strictly than does the terrestrial system, and in a large and deep lake vegetation is much less abundant than in a narrower and shallower one, not only relatively to the amount of water but also to the area of the bottom. From this deficiency of plant life results a deficiency of food for Entomostraca, whether of algæ, of Protozoa, or of higher forms, and hence, of course, a smaller number of the Entomostraca themselves, and these with more slender bodies, suitable for more rapid locomotion and wider range.

The difference of reproductive energy, as shown by the much smaller egg-masses borne by the species of the larger lakes, depends upon the vastly greater destruction to which the paludal Crustacea are subjected. Many of the latter occupy waters liable to be exhausted by drought, with a consequent enormous waste of entomostracan life. The opportunity for reproduction is here greatly limited-in some situations to early spring alone-and the chances for destruction of the stmmmer eggs in the dry and often dusty soil are so mumerous that only the most prolific species can maintain thenselves. 
Further, the marshes and shallower lakes are the favorite breeding grounds of fishes, which migrate to them in spawning time if possible, and it is from the Entomostraca found here that most young fishes get their earliest food supplies-a danger from which the deep-water spccies are measurably free. Not only is a high reproductive rate rendered unnecessary among the latter by their freedom from many dangers to which the shallow-ivater species are exposed, but in view of the relatively small amount of food available for them, a high rate of multiplication would be a positive injury, and could result only in wholesale starvation.

All these lakes of Illinois and Wisconsin, together with the much larger Lake Mendota at Madison (in which also I have done much work with dredge, trawl, and seine), differ in one notable particular both from Lake Michigan and from the larger lakes of Europe. In the latter the bottoms in the deeper parts yield a peculiar assemblage of animal forms which range but rarely into the littoral region, while in our inland lakes no such deep water fauna occurs, with the exception of the cisco and the large red Chironomus larva. At Grand Traverse Bay, in Lake Michigan, I found at a depth of one hundred fathoms a very odd fish of the sculpin fanily (Triglopsis thompsoni Gir.) which, until I collected it, had been known only from the stomachs of fishes; and there also was an abundant crustacean, Mysis-the "opossum shrimp", as it is sometimes called-the principal food of these deep lake sculpins. Two remarkable amphipod crustaceans also belong in a peculiar way to this deep water. In the European lakes the same Mysis occurs in the deepest part, with several other forms not represented in our collections, two of these being blind crustaceans related to those which in this conitry occur in caves and wells.

Comparing the other features of our lake fauna with that of Europe, we find a surprising number of Entomostraca identical; but this is a general phenomenon, as many of the more abundant Cladocera and Copepoda of our small wayside pools are either European species, or differ from them so slightly that it is cloubtful if they ought to be called distinct.

It would be quite impossible, within reasonable limits, to go into details respecting the organic relations of the animals of these waters, and I will content myself with two or three illustrations. As one example of the varied and far-reaching relations into which the animals of a lake are brought in the general struggle for life, I take the common black bass. In the dietary of this fish I find, at different ages of the individual, fishes of great variety, representing all the important orders of that class; insects in considerable number, especially the various water-bugs: and larva of day-fies; fresh-water shrimps; and a great multitude of Entomostraca of many species and genera. The fish is therefore directly dependent upon all these classes for its existence. Next, looking to the food of the species which the bass has eaten, and upon which it is therefore indirectly depenclent, I find that one kind of the fishes taken feeds upon mud, algæ, and Entomostraca, and another upon nearly every 
animal substance in the water, including mollusks and decomposing organic matter. The insects taken by the bass, themselves take other insects and small Crustacea. The crawfishes are nearly omnivorous, and of the other crustaceans some eat Entomostraca and some algæ and Protoza. At only the seconc step, therefore, we find our bass brought into dependence upon nearly every class of animals in the water.

And now, if we search for its competitors we shall find these also extremely numerous. In the first place, I have found that all our young fishes except the Catostomidæ feed at first almost wholly on Entomostraca, so that the little bass finds himself at the very beginning of his life engaged in a scramble for food with all the other little fishes in the lake. In fact, not only young fishes but a multitude of other animals as well, especially insects and the larger Crustacea, feed upon these Entomostraca, so that the competitors of the bass are not confined to members of its own class. Even mollusks, while they do not directly compete with it do so indirectly, for they appropriate myriads of the microscopic forms upon which the Entomostraca largely depend for fuod. But the enemies of the bass do not all attack it by appropriating its food supplies, for many devour the little fish itself. A great variety of predaceous fishes, turtles, water-snakes, wading and diving birds, and even bugs of gigantic dimensions destroy it on the slightest opportunity. It is in fact hardly too much to say that fishes which reach maturity are relatively as rare as centenarians among human kind.

As an illustration of the remote and unsuspected rivalries which reveal themselves on a careful study of such a situation, we may take the relations of fishes to the bladderwort ${ }^{1}$-a flowering plant which fills many acres of the water in the shallow lakes of northern Illinois. Upon the leaves of this species are found little bladders-several hundred to each plant-which when closely examined are seen to be tiny traps for the capture of Entomostraca and other minute animals. The plant usually has no roots, but lives entirely upon the animal food obtained through these little bladders. Ten of these sacs which I took at random from a mature plant contained no less than ninety-three animals (more than nine to a bladder), belonging to twenty-eight different species. Seventysix of these were Entomostraca, and eight others were minute insect larvæ. IVhen we estimate the myriads of small insects and Crustacea which these plants must appropriate during a year to their own support. and consider the fact that these are of the kinds most useful as food for young fishes of nearly all descriptions, we must conclude that the bladderworts compete with fishes for food, and tend to keep down their number by diminishing the food resources of the young. The plants even have a certain advantage in this competition, since they are not strictly dependent on Entomostraca, as the fishes are, but sometimes take root, developing then but very few leaves and bladders. This probably happens under conditions unfavorable to their support ly the other

Utricularia. 
method. These simple instances will suffice to illustrate the intimate way in which the living forms of a lake are united.

Perhaps no phenomenon of life in such a situation is more remarkable than the steady balance of organic nature, which holds each species within the limits of a uniform average number, year after year, although each one is always doing its best to break across boundaries on every side. The reproductive rate is usually enormous and the struggle for existence is correspondingly severe. Every animal within these bounds has its enemies, and Nature seems to have taxed her skill and ingenuity to the utmost to furnish these enemies with contrivances for the destruction of their prey in myriads. For every defensive device with which she has armed an animal, she has invented a still more effective apparatus of destruction and bestowed it upon some foe, thus striving with unending pertinacity to outwit herself; and yet life does not perish in the lake, nor even oscillate to any considerable degree, but on the contrary the little community secluded here is as prosperous as if its state were one of profound and perpetual peace. Although every species has to fight its way inch by inch from the egg to maturity, yet no species is exterminated, but each is maintained at a regular average number which we shall find good reason to believe is the greatest for which there is, year after year, a sufficient supply of food.

I will bring this paper to a close, already too long postponed, by endeavoring to show how this beneficent order is maintained in the midst of a conflict seemingly so lawless.

It is a self-evident proposition that a species can not maintain itself continuously, year after year, unless its birth-rate at least equals its deathrate. If it is preyed upon by another species, it must produce regularly an excess of individuals for destruction, or else it must certainlv dwindle and disappear. On the other hand, the dependent species evidently must not appropriate, on an average, any more than the surplus and excess of individuals upon which it preys, for if it does so it will continuously diminish its own food supply, and thus indirectly but surely exterminate itself. The interests of both parties will therefore be best served by an adjustment of their respective rates of multiplication such that the species devoured shall furnish an excess of numbers to supply the wants of the devourer, and that the latter shall confine its appropriations to the excess thus furnished. We thus see that there is really a close community of interest between these two seemingly deadly foes.

And next we note that this common interest is promoted by the process of natural selection; for it is the great office of this process to eliminate the unfit. If two species standing to each other in the relation of hunter and prey are or become badly adjusted in respect to their rates of increase, so that the one preyed upon is kept very far below the normal number which might find food, even if they do not presently: obliterate each other the pair are placed at a disadvantage in the battle for life, and must suffer accordingly. Just as certainly as the thrifty 
business man who lives within his income will finally dispossess his shiftless competitor who can never pay his debts, the well-adjusted aquatic animal will in time crowd out its poorly-adjusted competitors for food and for the various goods of life. Consequently we may believe that in the long run and as a general rule those species which have survived, are those which have reached a fairly close adjustment in this particular. ${ }^{1}$

Two ideas are thus seen to be sufficient to explain the order evolved from this seeming chaos; the first that of a general community of interests among all the classes of organic beings here assembled, and the second that of the beneficent power of natural selection which compels such adjustments of the rates of destruction and of multiplication of the various species as shall best promote this common interest.

Have these facts and idleas, derived from a study of our aquatic microcosm, any general application on a higher plane? WVe have here an example of the triumphant beneficence of the laws of life applied to conditions seemingly the most unfavorable possible for any mutually helpful adjustment. In this lake, where competitions are fierce and continuous beyond any parallel in the worst periods of human history; where they take hold, not on goods of life merely, but always upon life itself; where mercy and charity and sympathy and magnanimity and all the virtues are utterly unknown; where robbery and murder and the deadly tyranny of strength over weakness are the unvarying rule; where what we call wrong-doing is always triumphant, and what we call goodness would be immediately fatal to its possessor,- - even here, out of these hard conditions, an order has been evolved which is the best conceivable without a total change in the conditions themselves; an equilibrium has been reached and is steadily maintained that actually accomplishes for all the parties involved the greatest good which the circumstances will at all permit. In a system where life is the universal good. but the destruction of life the well-nigh universal occupation, an order has spontaneously arisen which constantly tends to maintain life at the highest limit-a limit far higher, in fact, with respect to both quality and quantity, than would be possible in the absence of this destructive conflict. Is there not, in this reflection, solid ground for a belief in the final beneficence of the laws of organic nature? If the system of life is such that a harmonious balance of conflicting interests has been reached where every element is either hostile or indifferent to every other, may we not trust much to the outcome where, as in human affairs, the spontaneous adjustments of nature are aided by intelligent effort, by sympathy, and by self-sacrifice?

For a fuller statement of this argument, see Bul. 1li. State lab. Nat. Hist. Vol. I. No. 3. pages 5 to 10 . 